\title{
Thiamylal sodium increased inflammation and the proliferation of vascular smooth muscle cells
}

\author{
Ryohei Miyazaki ${ }^{1}$ and Sumio Hoka ${ }^{2}$ \\ Department of Anesthesiology and Critical Care Medicine, ${ }^{1}$ Kyushu University Hospital, ${ }^{2}$ Graduate School of \\ Medical Sciences, Kyushu University, Fukuoka, Japan
}

\begin{abstract}
Background: Thiamylal sodium is a common anesthetic barbiturate prepared in alkaline solution for clinical use. There is no previously reported study on the effects of barbiturates on the inflammation and proliferation of vascular smooth muscle cells (VSMCs). Here, we examined the effects of clinical-grade thiamylal sodium solution (TSS) on the inflammation and proliferation of rat VSMCs.

Methods: Expression levels of interleukin (IL)-1 $\alpha$, IL-1 $\beta$, IL-6, and toll-like receptors in rat VSMCs were detected by quantitative reverse transcription-polymerase chain reaction and microarray analyses. The production of IL- 6 by cultured VSMCs or ex vivo-cultured rat aortic segments was detected in supernatants by enzyme-linked immunosorbent assay. VSMC proliferation and viability were determined by the water-soluble tetrazolium- 1 assay and trypan blue staining, respectively.

Results: TSS increased expression of IL-1 $\alpha$, IL-6, and TLR4 in VSMCs in a dose-dependent manner, and reduced IL-1 $\beta$ expression. Ex vivo TSS stimulation of rat aorta also increased IL-6. Low concentrations of TSS enhanced VSMC proliferation, while high concentrations reduced both cell proliferation and viability. Expression of IL-1 receptor antagonist, which regulates cell proliferation, was not increased by TSS stimulation. Exposure of cells to the TSS additive, sodium carbonate, resulted in significant upregulation of IL-1 1 and IL-6 mRNA levels, to a greater extent than TSS.

Conclusions: TSS-induced proinflammatory cytokine production by VSMCs is caused by sodium carbonate. However, pure thiamylal sodium has an anti-inflammatory effect in VSMCs. TSS exposure to VSMCs may promote vascular inflammation, leading to the progression of atherosclerosis or in-stent restenosis, resulting in vessel bypass graft failure.
\end{abstract}

Key Words: Inflammation, Interleukins, Thiamylal.

Corresponding author: Ryohei Miyazaki, M.D., Ph.D.

Department of Anesthesiology and Critical Care Medicine, Kyushu University Hospital, 3-1-1 Maidashi, Higashi-ku, Fukuoka 8128582, Japan

Tel: 81-926425714, Fax: 81-926425722

E-mail: miyaryou@kuaccm.med.kyushu-u.ac.jp

Received: November 6, 2015.

Revised: 1st, February 24, 2016; 2nd, March 22, 2016.

Accepted: March 25, 2016.

Korean J Anesthesiol 2016 June 69(3): 262-269

http://dx.doi.org/10.4097/kjae.2016.69.3.262

\section{Introduction}

Thiamylal sodium is a short-acting barbiturate used primarily for anesthesia induction and also in the management of intracranial hypertension [1]. Thiamylal-induced arterial vasodilation and myocardial depression are generally relatively mild [2]. Barbiturates are used in alkaline solutions ( $\mathrm{pH}$ 10.5-11.5) in many clinical settings, and following their venous injection, have been reported to cause phlebitis or thrombophlebitis [3]. However, there is no previously reported study on the effects of barbiturates on the inflammation response, or injury and proliferation of vascular smooth muscle cells (VSMCs).

In this study, we first screened clinical-grade thiamylal so-

(c) This is an open-access article distributed under the terms of the Creative Commons Attribution Non-Commercial License (http://creativecommons.org/ licenses/by-nc/4.0/), which permits unrestricted non-commercial use, distribution, and reproduction in any medium, provided the original work is properly cited. 
dium solution (TSS: Citosol)-responsive inflammatory related genes in a rat VSMC cell line using microarray analysis. Endogenous proinflammatory cytokines, including interleukin (IL)-1 $\alpha$, have been reported to promote a proliferative and proinflammatory phenotype in human VSMCs [4]. Inflammation and the proliferation of VSMCs, as well as cytokine secretion after vascular injury, contribute to the pathogenesis of atherosclerosis or in-stent restenosis, which can result in vessel bypass graft failure $[5,6]$. After an initial injury, growth factors and cytokines promote VSMC proliferation, migration, and extracellular matrix protein deposition [7]. We thus examined whether TSS could increase proinflammatory cytokine secretion from VSMCs and promote cell proliferation.

\section{Materials and Methods}

\section{Materials}

Dulbecco's modified Eagle's medium (DMEM) was purchased from Gibco BRL (Grand Island, NY, USA). Fetal bovine serum (FBS) was purchased from JRH Biosciences Inc. (Lenexa, KS, USA). Bovine serum albumin (BSA) was purchased from Sigma Chemical Co. (St. Louis, MO, USA). TSS (Citosol) was purchased from Kyorin Pharmaceutical Co. (Tokyo, Japan). Enzyme-linked immunosorbent assay (ELISA) kits for rat IL-1a and IL-6 were purchased from R\&D Systems, Inc. (Minneapolis, MN, USA) and BioSource International (Camarillo, CA, USA), respectively. The Water Soluble Tetrazolium-1 (WST) Cell Proliferation Assay System was purchased from Takara Bio (Shiga, Japan). All other chemical reagents, including sodium carbonate, were purchased from Wako Pure Chemicals (Osaka, Japan) unless otherwise stated.

\section{Cell culture}

Rat VSMCs (American Type Culture Collection, USA) were maintained in low-glucose DMEM supplemented with 5\% FBS at $37^{\circ} \mathrm{C}$ in a humidified atmosphere of $95 \%$ air and $5 \% \mathrm{CO}_{2}$. VSMCs were grown to confluence, then cultured for an additional 2 days in DMEM with $0.1 \%$ BSA prior to experimental use.

\section{Microarray analysis}

Rat VSMCs were treated with TSS for $3 \mathrm{~h}$ and total RNA was prepared using the acid guanidinium thiocyanate-phenolchloroform (AGPC) extraction method. Affymetrix GeneChip (Santa Clara, CA, USA) expression analysis, including sample preparation, hybridization and data analysis, was performed as described previously [8].

\section{Quantitative reverse transcription polymerase chain reaction (qRT-PCR)}

Total RNA samples from VSMCs treated with different concentrations of TSS or sodium carbonate were prepared using the AGPC extraction method with ISOGEN (Nippon Gene, Tokyo, Japan) according to the manufacturer's instructions. Total RNA $(0.4 \mu \mathrm{g})$ was reverse-transcribed using Moloney murine leukemia virus RT (ReverTra Ace-a kit; Toyobo, Osaka, Japan). IL and toll-like receptor (TLR) mRNA levels were measured using the SYBR-green (Toyobo) RT-PCR method and normalized to hypoxanthine phosphoribosyltransferase 1 (Hprt1) expression $(\mathrm{n}=4)$ [9]. The primer sequences used in this study are listed in Table 1. An ABI Prism 7500 Sequence Detection System (Applied Biosystems, Foster City, CA, USA) was used for detecting gene expression. Values are expressed as a percent of control culture (100\%).

\section{Cell proliferation assay}

VSMCs were plated in 96-well plates in DMEM. The culture

Table 1. Primer Sequences Used for Real-time qPCR

\begin{tabular}{lll}
\hline & \multicolumn{1}{c}{ Forward primer } & \multicolumn{1}{c}{ Reverse primer } \\
\hline Hprt & TCCTCATGGACTGATTATGGACA & TAATCCAGCAGGTCAGCAAAGA \\
IL-1 $\alpha$ & GAAGACAAGCCTGTGTTGCTGAA & AGGTCGGTCTCACTACCTGTGATG \\
IL-1 $\beta$ & CCCTGAACTCAACTGTGAAATAGCA & CCCAAGTCAAGGGCTTGGAA \\
IL-1Ra & TGGAGATGACACCAAGCTCCAG & GTCTCGGAGCGGATGAAGGTAA \\
IL-6 & TGGATGAGCTGAACTGTACCC & GCTTGCCAAGGATTGTGAGT \\
TLR2 & GGCCACAGGACTCAAGAGCA & AGAGGCCTATCACAGCCATCAAG \\
TLR3 & AGGTATTGAACCTGCAACACAATGA & CCCAAGTTCCCAACTTTGTAGATGA \\
TLR4 & CTCACAACTTCAGTGGCTGGATTTA & GTCTCCACAGCCACCAGATTCTC \\
TLR5 & CCACCAAGGACTGCGATGAA & TTTGTGACTATGAGGGTGATGACGA \\
TLR6 & AGTGCACCAGGGTTCCAGATG & TTAAGGCCAGGGTGCAAACAA \\
\hline
\end{tabular}

Hprt1: hypoxanthine phosphoribosyltransferase 1, IL: interleukin, TLR: toll-like receptor. 
medium was replaced the following day with fresh medium containing different concentrations of TSS and the VSMCs were cultured for a further $24 \mathrm{~h}$. Proliferation was measured using the WST-1 assay $(\mathrm{n}=10)$ [10]. Briefly, premixed WST-1 reagent $(10 \mu \mathrm{l})$ was added to each well and VSMCs were incubated for $4 \mathrm{~h}$. Sample absorbance, compared with a background blank control, was measured at $450 \mathrm{~nm}$ using a microplate reader according to the manufacturer's instructions.

\section{Quantification of rat IL-6 by ELISA}

Based on our previous preliminary data to detect a significant increase in IL-6 protein level [11], VSMCs were stimulated with TSS for $24 \mathrm{~h}$. VSMC culture supernatants were collected and centrifuged (12000 rpm, $1 \mathrm{~min}$ ). Supernatants were stored at $-80^{\circ} \mathrm{C}$ until later use in assays. ELISA was carried out to determine IL- 6 protein expression levels according to the manufacturer's instructions $(n=8)$.

\section{Ex vivo stimulation of rat aorta}

Nine-week-old Sprague Dawley rats were purchased from Kyudo Co. (Saga, Japan). Animal handling was supervised by the Institutional Animal Experiment Committee. Rats were euthanized under deep anesthesia with pentobarbital and ketamine. The thoracic-aorta was excised and the adventitia was removed. The aorta was cut into small pieces and about $5 \mathrm{~g}$ (wet weight) of tissue was stimulated with or without $30 \mu \mathrm{M}$ TSS in $500 \mu \mathrm{l}$ DMEM supplemented with $0.1 \%$ BSA for $24 \mathrm{~h}$ in 12 -well plates [11]. Supernatants were collected and centrifuged $(12,000$ $\mathrm{rpm}, 1 \mathrm{~min}$ ) prior to being stored at $-80^{\circ} \mathrm{C}$ until further use in assays to measure IL-1 $\alpha$ or IL- 6 production by ELISA $(n=5)$. The IL- 6 concentration in the supernatant was normalized with the wet weight of the aortic segment.

\section{Measurement of cell viability}

Confluent VSMCs were serum-starved for $24 \mathrm{~h}$ prior to treatment with TSS. After $24 \mathrm{~h}$ incubation, attached cells were harvested with trypsin-EDTA. Cells in the medium were collected by centrifugation and then stained with $0.4 \%$ trypan blue. Numbers of total and dead cells were counted using a hemocytometer $(n=8)$ [12]. Values are expressed as a percent of control culture (100\%).

\section{Statistical analysis}

Normality of the data was assessed with the Shapiro-Wilk test. A t-test was used to compare between two groups. Evaluation of differences between multiple groups was performed using one-way analysis of variance (ANOVA) and Fisher's post hoc test, as appropriate. All analyses were performed using JMP Pro software (ver. 11; SAS Institute Inc., Cary, NC, USA). Data are presented as means \pm standard error of the mean (SEM). A probability value of $\mathrm{P}<0.05$ with a $95 \%$ confidence interval was considered to indicate a statistically significant difference.

\section{Results}

\section{Microarray analysis}

Following TSS-responsive gene screening in rat VSMCs using a microarray, TSS was found to enhance expression of several genes involved in inflammation (Table 2).

\section{TSS enhances inflammatory response in VSMCs}

Exposure of VMSCs to TSS at a dose of $100 \mu \mathrm{M}$ resulted in upregulation of IL-1 $\alpha$ mRNA $(3,262.9 \% \pm 1,195.0 \%$ vs. Control (100\%), P = 0.005; Fig. 1A). However, TSS at doses of 3, 10, 30, and $100 \mu \mathrm{M}$ resulted in downregulation of IL- $1 \beta$ mRNA $(15.9 \%$ $\pm 4.1 \%$ vs. Control, $\mathrm{P}=0.045 ; 4.2 \% \pm 4.1 \%, \mathrm{P}=0.022 ; 17.2 \% \pm$ $9.2 \%, \mathrm{P}=0.049 ; 4.5 \% \pm 2.8 \%, \mathrm{P}=0.023$, respectively; Fig $1 \mathrm{~B})$ in a dose-dependent manner (Figs. $1 \mathrm{~A}$ and $1 \mathrm{~B}$ ). A similar trend was observed for IL-6 mRNA $(443.1 \% \pm 61.2 \%$ vs. Control, P < 0.001 at $100 \mu \mathrm{M}$; Fig. 1C).

Receptor-mediated activation of VSMCs can contribute to increased inflammatory responses; thus, we next investigated TLR expression patterns. VSMCs stimulated by TSS at doses of 30 and $100 \mu \mathrm{M}$ showed a mild but significant increase in TLR4 mRNA expression in a dose-dependent manner $(134.5 \% \pm 5.7 \%$ vs. Control, $\mathrm{P}=0.001 ; 163.5 \% \pm 7.9 \%, \mathrm{P}<0.001$, respectively; Fig. 2A). Although TLR5 mRNA showed a tendency to increase, the difference was not significant $(\mathrm{P}=0.152$ at $100 \mu \mathrm{M}$; Fig. $2 \mathrm{~B})$. Finally, levels of TLR2, TLR3, and TLR6 mRNA expression were very low and did not change markedly.

Table 2. Microarray Analyses of Endogenous Gene Expression in VSMCs Treated with Thiamylal Sodium Solution (TSS) Versus Vehicle Controls

\begin{tabular}{lc}
\hline \multicolumn{1}{c}{ Gene } & Fold-change* $^{*}$ \\
\hline Chemokine (C-X3-C motif) ligand 1 (Cx3cl1) & 2.02 \\
Interleukin 1 receptor antagonist (IL-1Ra) & 1.74 \\
Interleukin 6 (IL-6) & 1.60 \\
Interleukin 16 (IL-16) & 1.46 \\
Interleukin 1 receptor type I (IL-1R1) & 1.33
\end{tabular}

*Ratios represent the fold-activation of gene expression in cells treated with TSS for $3 \mathrm{~h}$ versus vehicle controls. 
A

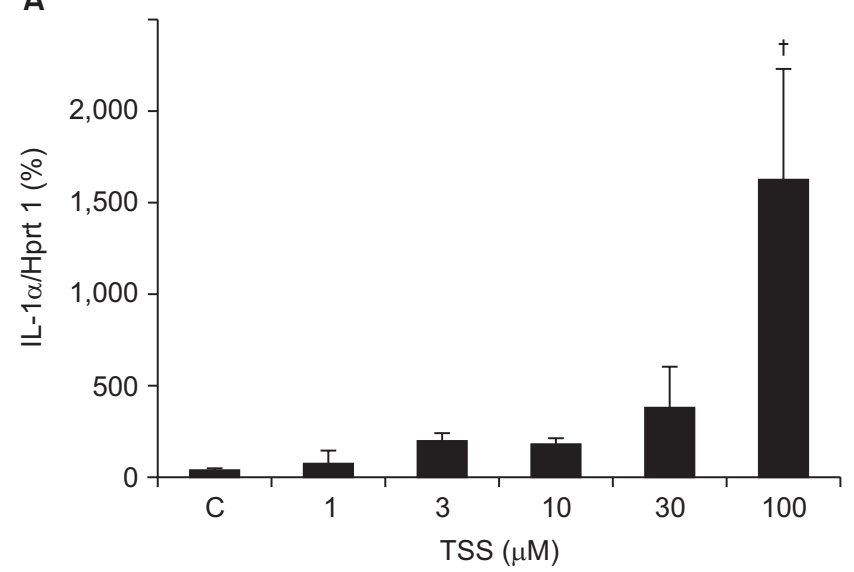

C

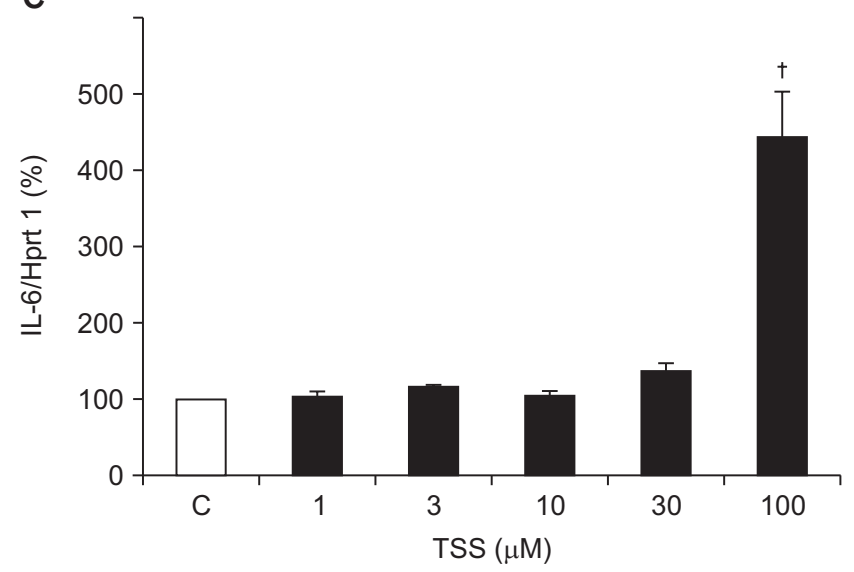

B

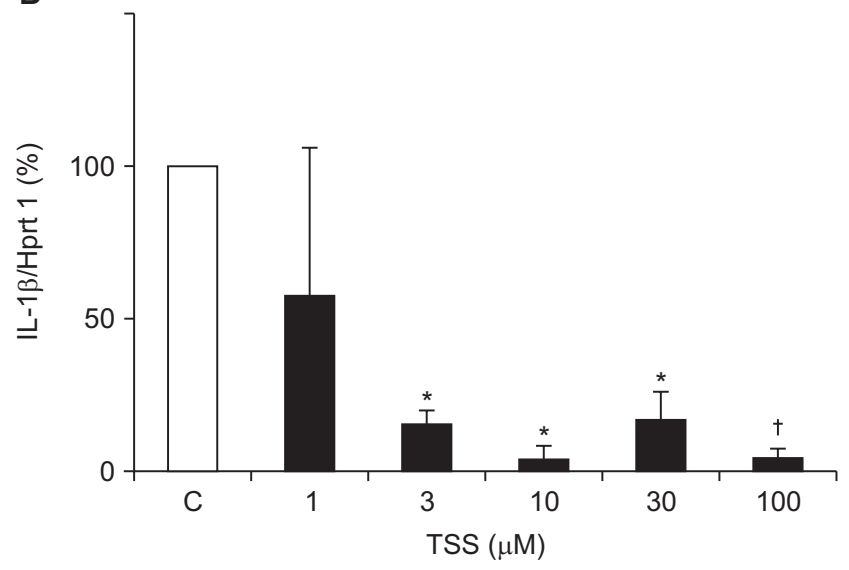

Fig. 1. Upregulation of proinflammatory cytokine expression by thiamylal sodium solution (TSS) in vascular smooth muscle cells (VSMCs). VSMCs were incubated with TSS at various concentrations for $3 \mathrm{~h}(\mathrm{n}=4)$. Expression levels of each mRNA transcript were determined by qRT-PCR and normalized to hypoxanthine phosphoribosyltransferase 1 (Hprt1) mRNA expression levels. Values are expressed as a percentage of the control culture $(100 \%) ;{ }^{*} \mathrm{P}<0.05,{ }^{\dagger} \mathrm{P}<0.01$ vs. controls. All data are shown as the mean \pm SEM.

B
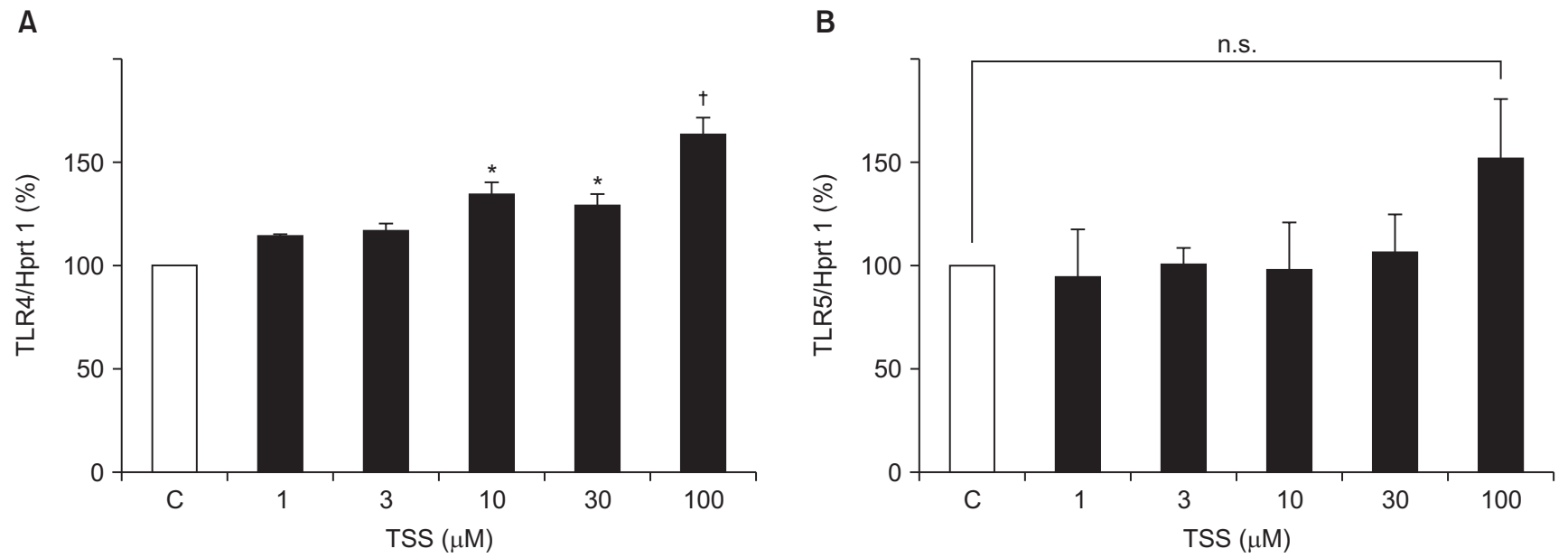

Fig. 2. Upregulation of toll-like receptor expression by TSS in VSMCs. VSMCs were incubated with TSS at various concentrations for $3 \mathrm{~h}(\mathrm{n}=4)$. Expression levels of toll-like receptors were determined as described in the Fig. 1 legend. ${ }^{*} \mathrm{P}<0.05,{ }^{\dagger} \mathrm{P}<0.01$ vs. controls. All data are shown as the mean \pm SEM.

\section{TSs increases IL-6 production In Vitro and Ex Vivo}

VSMCs were incubated with TSS for $24 \mathrm{~h}$. TSS-induced IL- 6 production was significantly increased in a dose-dependent manner (Control $16.4 \pm 6.5 \mathrm{pg} / \mathrm{ml}$ [range: $0.91-31.85 \mathrm{pg} / \mathrm{ml}]$; TSS $[10 \mu \mathrm{M}] 119.2 \pm 28.4 \mathrm{pg} / \mathrm{ml}$ [range: $51.9-186.4 \mathrm{pg} / \mathrm{ml}], \mathrm{P}$ $=0.145 ;$ TSS $[30 \mu \mathrm{M}] 194.8 \pm 78.1 \mathrm{pg} / \mathrm{ml}$ [range: $10.1-379.6$ $\mathrm{pg} / \mathrm{ml}], \mathrm{P}=0.015$; Fig. $3 \mathrm{~A}$ ). To confirm that proinflammatory 
A

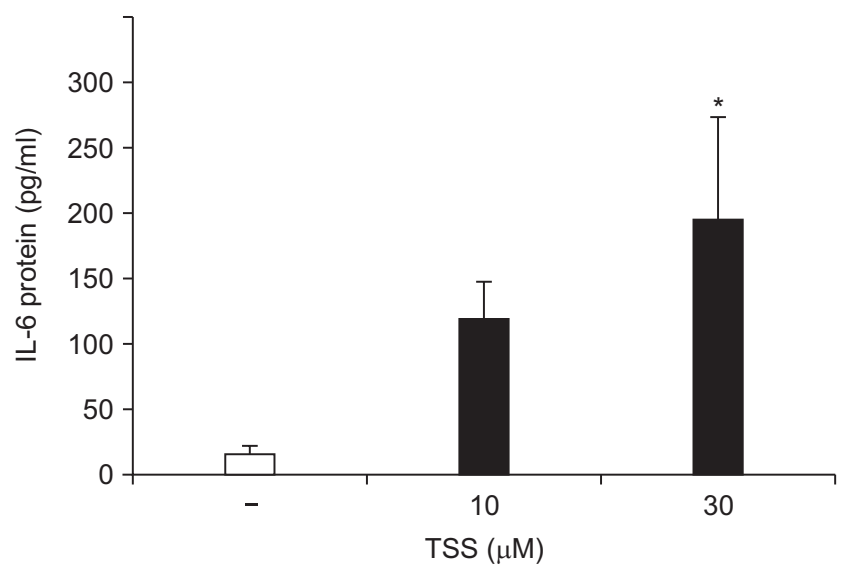

B

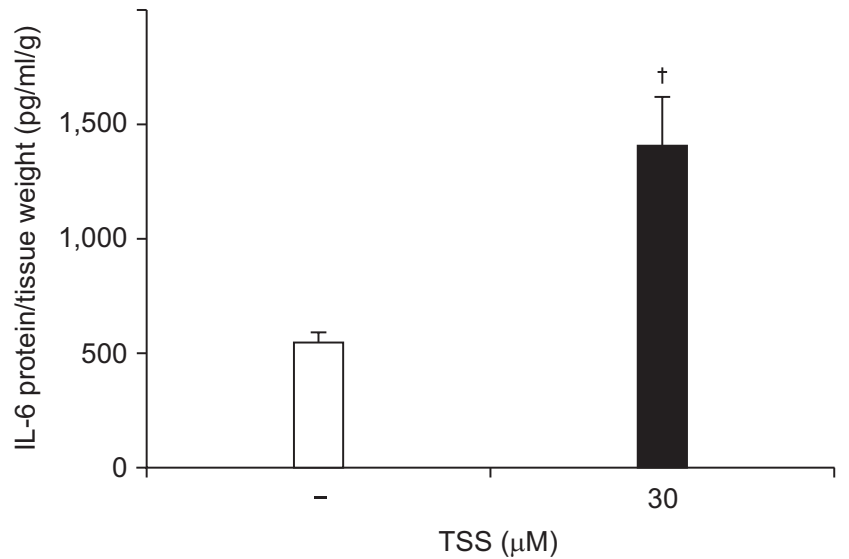

Fig. 3. TSS-induced interleukin (IL)-6 production. (A) Vascular smooth muscle cells were stimulated with various concentrations of TSS for $24 \mathrm{~h}$ (n = 8). IL-6 production in the culture medium was measured by enzyme-linked immunosorbent assay (ELISA). (B) An aortic segment was stimulated ex vivo with TSS in Dulbecco's modified Eagle's medium (DMEM) supplemented with $0.1 \%$ bovine serum albumin (BSA) for $24 \mathrm{~h}$. The concentration of IL- 6 in the supernatant was measured and normalized to the wet weight of the aortic segment $(\mathrm{n}=5) ;{ }^{*} \mathrm{P}<0.05,{ }^{\dagger} \mathrm{P}<0.01$ vs. controls. All data are shown as the mean \pm SEM.

cytokines were produced from blood vessels, a segment of rat aorta without adventitia was stimulated ex vivo with TSS for 24 h. IL-6 production from rat aorta was increased by TSS stimulation (Control $551.2 \pm 43.5 \mathrm{pg} / \mathrm{ml} / \mathrm{g}$ [range: $430.3-802.4 \mathrm{pg} / \mathrm{ml}$ ] vs. TSS $1,405 \pm 43.5 \mathrm{pg} / \mathrm{ml} / \mathrm{g}$ [range: $802.4-2,009.0 \mathrm{pg} / \mathrm{ml}$ ], P = 0.005 ; Fig. $3 \mathrm{~B}$ ). IL- $1 \alpha$ production in the medium was undetectable under these conditions (data not shown). These ex vivo results are consistent with those obtained during the in vitro experiments.

\section{TSS attenuates cell proliferation and viability}

TLR-activated VSMCs have been reported to produce IL$1 \alpha$ in an autocrine manner, which contributes to proliferation and chemokine release by VSMCs [4]. VSMCs were cultured with TSS for $24 \mathrm{~h}$ and the effect of TSS on proliferation was determined. The WST- 1 cell proliferation assay showed that a low concentration of TSS increased cell proliferation of VSMCs (percentage proliferation at $10 \mu \mathrm{M}$ TSS: $124 \% \pm 21 \%$ vs. Control [range: 109\%-140\%], P = 0.002; Fig. 4A). In contrast, the highest concentration of TSS inhibited VMSC proliferation (percent proliferation $100 \mu \mathrm{M}$ TSS: $43 \% \pm 2 \%$ vs. Control [range: $40 \%-$ $46 \%$ ], $\mathrm{P}<0.001$ ).

Cell viability was assessed by trypan blue staining. TSS at the highest concentration significantly reduced the viability of VSMCs (percentage of viable cells at $30 \mu \mathrm{M}$ TSS: $87 \% \pm 3 \%$ [range: $80 \%-94 \%$ ], $\mathrm{P}=0.015 ; 100 \mu \mathrm{M}$ TSS: $69 \% \pm 4 \%$ [range: 61\%-77\%], P < 0.001; Fig. 4B). It has been reported that VSMCs produce IL-1 receptor antagonist (IL-1Ra) that inhibits the activities of IL-1 $\alpha$ and IL-1 $\beta$ and regulates both inflammatory responses and cell proliferation [13-15]. However, IL-Ra mRNA was not significantly increased by TSS stimulation $(100 \mu \mathrm{M}$ TSS: $\mathrm{P}=0.521$; Fig. 4C).

\section{Effects of sodium carbonate on VSMCs}

Finally, we investigated the effects of sodium carbonate on VSMCs. TSS contains $0.035 \mathrm{~g}$ of sodium carbonate per $0.5 \mathrm{~g}$ of thiamylal sodium $(0.18 \mu \mathrm{M}$ of sodium carbonate per $1 \mu \mathrm{M}$ of thiamylal sodium). VSMCs were stimulated with the same amount of sodium carbonate contained in TSS (Fig. 1). IL-1 $\alpha$ mRNA levels $(1,734.0 \% \pm 363.2 \%$ vs. Control, $\mathrm{P}=0.019$ at 5.47 $\mu \mathrm{M} ; 3,633.1 \% \pm 762.8 \%, \mathrm{P}<0.001$ at $18.25 \mu \mathrm{M})$ and IL- 6 mRNA levels $(286.9 \% \pm 73.8 \%$ vs. Control, $\mathrm{P}=0.046$ at $1.82 \mu \mathrm{M} ; 291.4 \%$ $\pm 25.1 \%, \mathrm{P}=0.042$ at $5.47 \mu \mathrm{M} ; 537.5 \% \pm 133.7 \%, \mathrm{P}<0.001$ at $18.25 \mu \mathrm{M}$ ) were significantly upregulated by sodium carbonate stimulation (Fig. 5). However, the increase in levels of ILs was considerably greater using sodium carbonate alone than with TSS (Fig. 1).

\section{Discussion}

In the present study, we demonstrated that TSS increased the expression of IL-1 $\alpha$ and IL- 6 in VSMCs. Low concentrations of TSS showed a positive effect on the proliferation of VSMCs. TSS contains a sodium carbonate additive because thiamylal sodium is difficult to dissolve at neutral $\mathrm{pH}$. Because sodium carbonate produces hydroxide ions in aqueous solution, thiamylal is always used in strong alkaline solutions in the clinical setting. Consequently, intravenous injection of barbiturates, including TSS, of- 
A

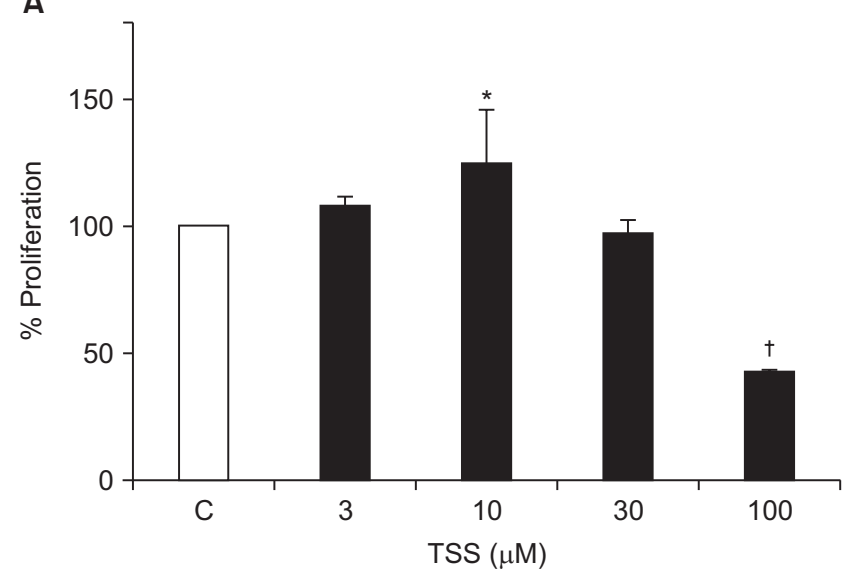

C

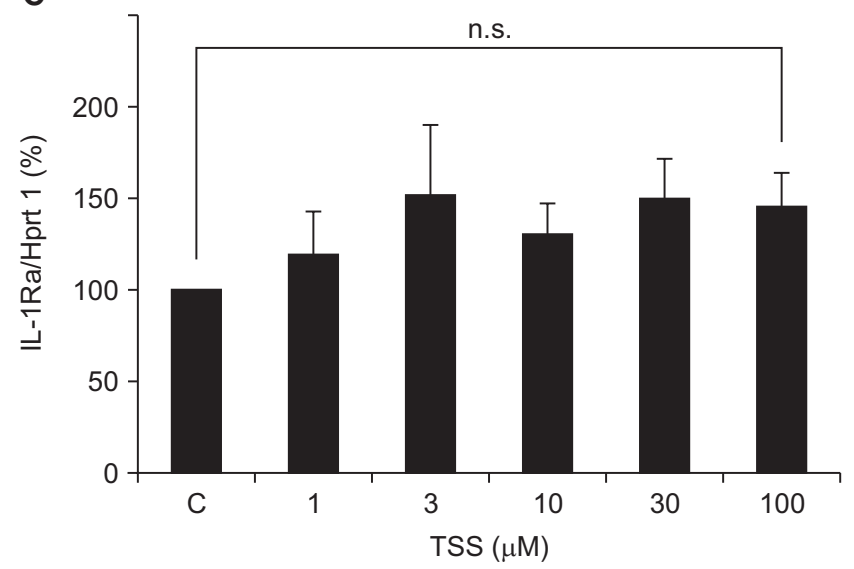

B

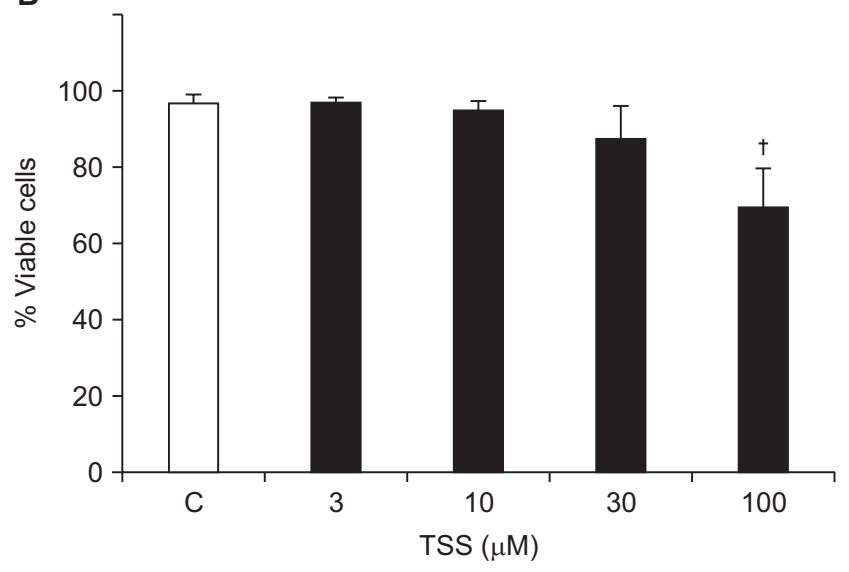

Fig. 4. Effect of TSS on VSMC proliferation. (A) Cells were exposed to various concentrations of TSS for $24 \mathrm{~h}$, after which the growth rate was measured using the Water Soluble Tetrazolium-1 (WST-1) assay $(n=8 /$ group). (B) VSMCs were treated with TSS for $24 \mathrm{~h}$. Detached VSMCs were collected and stained with trypan blue. (C) Quantitative reverse transcription polymerase chain reaction (qRT-PCR) analysis of IL-1 receptor antagonist (IL-1Ra) was performed as described in the Fig. 1 legend; ${ }^{*} \mathrm{P}<0.05,{ }^{\dagger} \mathrm{P}<0.01$ vs. controls. All data are shown as the mean \pm SEM.

B
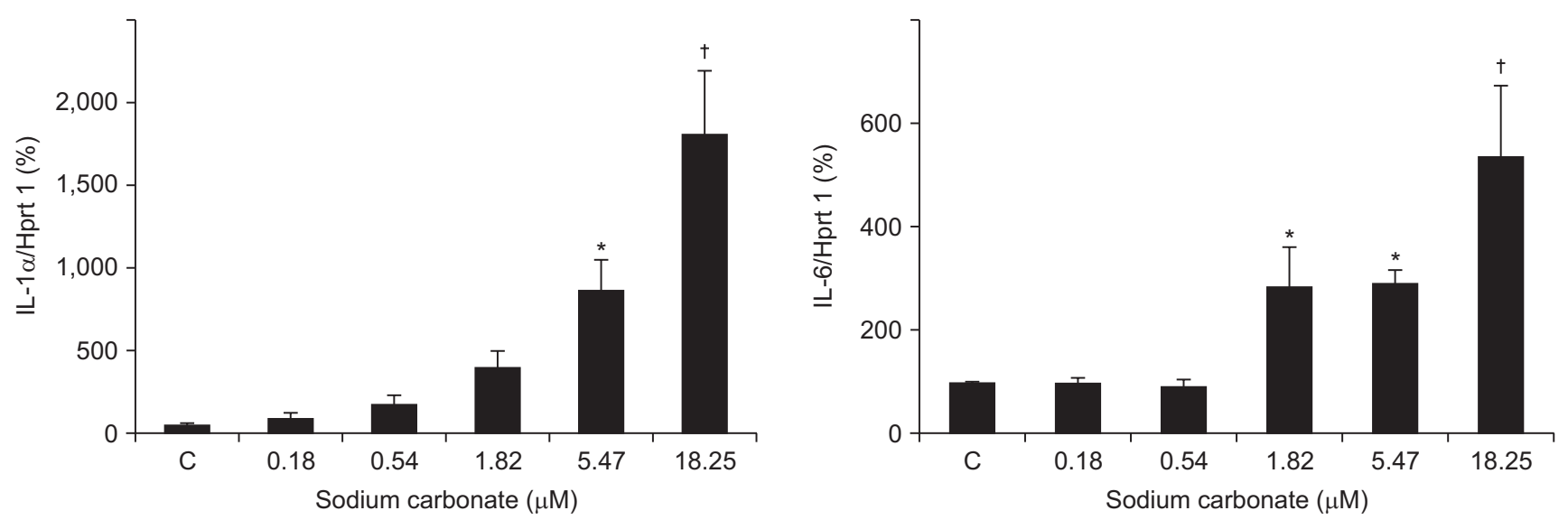

Fig. 5. Upregulation of proinflammatory cytokine expression by sodium carbonate in VSMCs. VSMCs were incubated with sodium carbonate at various concentrations for $3 \mathrm{~h}(\mathrm{n}=4)$. Expression levels of each mRNA transcript were determined by qRT-PCR and normalized to hypoxanthine phosphoribosyltransferase 1 (Hprt1) mRNA expression levels. Values are expressed as a percentage of the control culture $(100 \%) ;{ }^{*} \mathrm{P}<0.05,{ }^{\dagger} \mathrm{P}<0.01$ vs. controls. All data are shown as the mean \pm SEM.

ten causes phlebitis or local necrosis at the injection site. In this study, sodium carbonate-induced IL- $1 \alpha$ and IL- 6 upregulation was greater than TSS-induced upregulation. These results indi- cate that TSS-induced proinflammatory cytokine production by VSMCs is likely to be caused by sodium carbonate, whereas pure thiamylal sodium itself has a potent anti-inflammatory effect in 
VSMCs.

A previous study indicated that endogenous IL-1 $\alpha$ acts as an autocrine growth factor for VSMCs, and its pro-proliferative effects are mediated by signaling via the type-1 IL-1 receptor $[4,16]$. IL-6 is well-known to induce the expression of C-reactive protein, which is a prognostic marker for atherosclerotic cardiovascular disease [17]. Furthermore, IL-6 stimulates the proliferation of VSMCs [18]. These data suggest that IL-6 from blood vessels could be involved in local inflammatory responses that might accelerate atherogenesis. Furthermore, some clinical studies suggest that inflammatory mediators, including oxidized low-density lipoprotein, IL-6, and tumor necrosis factor- $\alpha$, are associated with an increase in the relative risk of developing cardiovascular disease, especially ischemic heart disease [19-21]. We showed that TSS increased proinflammatory cytokine production from rat VSMCs and aortas. These findings indicate that TSS-induced proinflammatory cytokine production might, at least partially, contribute to the progression of atherosclerosis.

Clarke et al. [22] showed that necrotic VSMCs release IL-1a, which subsequently stimulates the surrounding viable VSMCs to release IL-6 and monocyte chemotactic protein (MCP)-1. In the present study, TSS increased the expression of IL-1 $\alpha$ but not IL- $1 \beta$ mRNA expression. Additionally, the WST-1 assay and trypan blue viability test suggest that high concentrations of TSS reduced cell viability. Both apoptosis and necrosis can occur at high levels in advanced plaques in conjunction with high serum concentrations of inflammatory factors [23]. Considered together, TSS might contribute to the development of VSMC necrosis and cause plaque build-up.

Members of the TLR family play key roles in the innate immune system and are expressed in a cell type-specific manner [24]. TSS-stimulated VSMCs showed a significant increase in TLR4 mRNA expression level. Previous studies have shown that TLR4 is associated with VSMC proliferation $[25,26]$. In the pres- ent study, TSS-induced VSMC proliferation was observed only at a concentration of $10 \mu \mathrm{M}$. At this concentration, however, IL levels did not significantly increase. Based on these findings, it is presumed that the effect of TSS on VSMC proliferation is associated primarily with TLR4 upregulation. Earlier studies indicate that TLR4 expression on VSMCs is linked to elevated basal secretion of IL-6 [27]. TSS-induced TLR4 upregulation may play a partial role in the secretion of IL-6. Although TLR3 signaling can evoke proinflammatory and proliferative responses in human VSMCs [28], overall levels of TLR3 mRNA expression were very low in our study.

VSMCs can express an intracellular form of IL-1Ra that regulates inflammatory responses and cell proliferation [13]. A previous study showed that the effect of transforming growth factor (TGF)- $\beta 1$ on IL-1Ra production could be completely inhibited by an anti-IL-1 $\beta$ antibody [15]. In our study, neither IL-1Ra nor IL-1 $\beta$ expression were increased in TSS-stimulated VSMCs. IL$1 \mathrm{Ra}$ induction in VSMCs might therefore be dependent on IL$1 \beta$ expression.

Clinically relevant plasma concentrations of thiamylal (2.7-5.0 $\mathrm{mg} / \mathrm{kg}$ ), 2-30 min after bolus intravenous injection, are reported to range between 7.8 and $47.0 \mu \mathrm{M}$ [29]. Furthermore, the initial concentration of thiamylal in clinical use is about $200 \mu \mathrm{M}$ [30]. Thus, the concentrations of thiamylal used in our study represent pharmacologically achievable plasma concentrations. However, because of the numerous limitations of in vitro studies, in vivo studies are needed to confirm whether thiamylal causes the development of blood vessel inflammation.

In summary, we showed that TSS increased IL- $1 \alpha$ and IL- 6 production both in vitro and ex vivo, and that low concentrations of TSS increased VSMC proliferation. These effects may promote vascular inflammation and lead to the progression of atherosclerosis.

\section{References}

1. Marshall GT, James RF, Landman MP, O'Neill PJ, Cotton BA, Hansen EN, et al. Pentobarbital coma for refractory intra-cranial hypertension after severe traumatic brain injury: mortality predictions and one-year outcomes in 55 patients. J Trauma 2010; 69: 275-83.

2. Kaplan JA, Guffin AV, Mikula S, Dolman J, Profeta J. Comparative hemodynamic effects of propofol and thiamylal sodium during anesthetic induction for myocardial revascularization. J Cardiothorac Anesth 1988; 2: 297-302.

3. Hewitt JC, Hamilton RC, O'Donnell JF, Dundee JW. Clinical studies of induction agents. XIV: A comparative study of venous complications following thiopentone, methohexitone and propanidid. Br J Anaesth 1966; 38: 115-8.

4. Schultz K, Murthy V, Tatro JB, Beasley D. Endogenous interleukin-1 alpha promotes a proliferative and proinflammatory phenotype in human vascular smooth muscle cells. Am J Physiol Heart Circ Physiol 2007; 292: H2927-34.

5. Andrés V, Castro C. Antiproliferative strategies for the treatment of vascular proliferative disease. Curr Vasc Pharmacol 2003; 1: 85-98.

6. Smith TP. Atherosclerosis and restenosis: an inflammatory issue. Radiology 2002; 225: 10-2.

7. Rudijanto A. The role of vascular smooth muscle cells on the pathogenesis of atherosclerosis. Acta Med Indones 2007; $39: 86-93$.

8. Dalmas DA, Scicchitano MS, Chen Y, Kane J, Mirabile R, Schwartz LW, et al. Transcriptional profiling of laser capture microdissected rat arterial elements: fenoldopam-induced vascular toxicity as a model system. Toxicol Pathol 2008; 36: 496-519. 
9. Matsuura H, Ichiki T, Inoue E, Nomura M, Miyazaki R, Hashimoto T, et al. Prolyl hydroxylase domain protein 2 plays a critical role in dietinduced obesity and glucose intolerance. Circulation 2013; 127: 2078-87.

10. Zheng N, Ding X, Jahan R. Low concentration of rapamycin inhibits hemangioma endothelial cell proliferation, migration, and vascular tumor formation in mice. Curr Ther Res Clin Exp 2014; 76: 99-103.

11. Tian Q, Miyazaki R, Ichiki T, Imayama I, Inanaga K, Ohtsubo H, et al. Inhibition of tumor necrosis factor-alpha-induced interleukin-6 expression by telmisartan through cross-talk of peroxisome proliferator-activated receptor-gamma with nuclear factor kappaB and CCAAT/ enhancer-binding protein-beta. Hypertension 2009; 53: 798-804.

12. Miyazaki R, Ichiki T, Hashimoto T, Inanaga K, Imayama I, Sadoshima J, et al. SIRT1, a longevity gene, downregulates angiotensin II type 1 receptor expression in vascular smooth muscle cells. Arterioscler Thromb Vasc Biol 2008; 28: 1263-9.

13. Porreca E, Di Febbo C, Barbacane RC, Panara MR, Cuccurullo F, Conti P. Effect of interleukin-1 receptor antagonist on vascular smooth muscle cell proliferation. Atherosclerosis 1993; 99: 71-8.

14. Kim HJ, Kim MY, Hwang JS, Kim HJ, Lee JH, Chang KC, et al. PPARdelta inhibits IL-1beta-stimulated proliferation and migration of vascular smooth muscle cells via up-regulation of IL-1Ra. Cell Mol Life Sci 2010; 67: 2119-30.

15. Di Febbo C, Baccante G, Reale M, Castellani ML, Angelini A, Cuccurullo F, et al. Transforming growth factor beta1 induces IL-1 receptor antagonist production and gene expression in rat vascular smooth muscle cells. Atherosclerosis 1998; 136: 377-82.

16. Beasley D, Cooper AL. Constitutive expression of interleukin-1alpha precursor promotes human vascular smooth muscle cell proliferation. Am J Physiol 1999; 276: H901-12.

17. Ridker PM, Rifai N, Rose L, Buring JE, Cook NR. Comparison of C-reactive protein and low-density lipoprotein cholesterol levels in the prediction of first cardiovascular events. N Engl J Med 2002; 347: 1557-65.

18. Yao JS, Zhai W, Fan Y, Lawton MT, Barbaro NM, Young WL, et al. Interleukin-6 upregulates expression of KDR and stimulates proliferation of human cerebrovascular smooth muscle cells. J Cereb Blood Flow Metab 2007; 27: 510-20.

19. Lobbes MB, Lutgens E, Heeneman S, Cleutjens KB, Kooi ME, van Engelshoven JM, et al. Is there more than C-reactive protein and fibrinogen? The prognostic value of soluble CD40 ligand, interleukin- 6 and oxidized low-density lipoprotein with respect to coronary and cerebral vascular disease. Atherosclerosis 2006; 187: 18-25.

20. Luc G, Bard JM, Juhan-Vague I, Ferrieres J, Evans A, Amouyel P, et al. C-reactive protein, interleukin-6, and fibrinogen as predictors of coronary heart disease: the PRIME Study. Arterioscler Thromb Vasc Biol 2003; 23: 1255-61.

21. Naya M, Tsukamoto T, Morita K, Katoh C, Furumoto T, Fujii S, et al. Plasma interleukin-6 and tumor necrosis factor-alpha can predict coronary endothelial dysfunction in hypertensive patients. Hypertens Res 2007; 30: 541-8.

22. Clarke MC, Talib S, Figg NL, Bennett MR. Vascular smooth muscle cell apoptosis induces interleukin-1-directed inflammation: effects of hyperlipidemia-mediated inhibition of phagocytosis. Circ Res 2010; 106: 363-72.

23. Han DK, Haudenschild CC, Hong MK, Tinkle BT, Leon MB, Liau G. Evidence for apoptosis in human atherogenesis and in a rat vascular injury model. Am J Pathol 1995; 147: 267-77.

24. Sabroe I, Parker LC, Dower SK, Whyte MK. The role of TLR activation in inflammation. J Pathol 2008; 214: 126-35.

25. de Graaf R, Kloppenburg G, Kitslaar PJ, Bruggeman CA, Stassen F. Human heat shock protein 60 stimulates vascular smooth muscle cell proliferation through Toll-like receptors 2 and 4. Microbes Infect 2006; 8: 1859-65.

26. Pi Y, Zhang LL, Li BH, Guo L, Cao XJ, Gao CY, et al. Inhibition of reactive oxygen species generation attenuates TLR4-mediated proinflammatory and proliferative phenotype of vascular smooth muscle cells. Lab Invest 2013; 93: 880-7.

27. Song Y, Shen H, Schenten D, Shan P, Lee PJ, Goldstein DR. Aging enhances the basal production of IL-6 and CCL2 in vascular smooth muscle cells. Arterioscler Thromb Vasc Biol 2012; 32: 103-9.

28. Yang X, Murthy V, Schultz K, Tatro JB, Fitzgerald KA, Beasley D. Toll-like receptor 3 signaling evokes a proinflammatory and proliferative phenotype in human vascular smooth muscle cells. Am J Physiol Heart Circ Physiol 2006; 291: H2334-43.

29. Akata T. General anesthetics and vascular smooth muscle: direct actions of general anesthetics on cellular mechanisms regulating vascular tone. Anesthesiology 2007; 106: 365-91.

30. Hirshman CA, Edelstein RA, Ebertz JM, Hanifin JM. Thiobarbiturate-induced histamine release in human skin mast cells. Anesthesiology $1985 ; 63: 353-6$. 